\title{
Estimating Chlorophyll-A Concentration using Remote Sensing Techniques
}

\author{
Şeyma Merve Kaymaz ${ }^{1 *}$ and Ersin Ates $^{2}$ \\ ${ }^{1}$ Turkish Marine Research Foundation, Turkey \\ ${ }^{2}$ Department of Geology, Mugla Sitkl Kocman University, Turkey
}

Submission: September 10, 2018; Published: October 26, 2018

"Corresponding author: Şeyma Merve Kaymaz, Turkish Marine Research Foundation, Istanbul, Turkey, Tel: +905553440639;

Email: seymamerve@tudav.org

\section{Abstract}

Chlorophyll-a is used as an indicator of the mass of phytoplankton, and as a reference for estimating organic influence in the aquatic area. This study discusses the spatio-temporal distribution of chlorophyll-a in the Marmaris Bay. The aim of the study is to be a source of information on how to use remote sensing technology in the marine field. Chl-a level is identified using Sentinel 2A satellite images in the May 2017 and May 2018. The chl-a levels were higher in the coastal areas than the open sea. The results obtained from the satellite images should be compared with the laboratory results and the accuracy should be confirmed.

Keywords: Chlorophyll-a; Remote sensing; Sentinel 2A; Algorithm; Estimation

\section{Introduction}

Chlorophyll-a is found in algae and other phytoplankton in the surface water. Chlorophyll-a is one of the ecological indicators used to evaluate the ecological status of marine environment. This pigment cell is used to energy from sunlight to produce oxygen for life-sustaining. To monitor chlorophyll levels is a way of tracking algal growth. The high chlorophyll levels are high in nutrients in the surface waters. The nutrients cause the growth of algae. When populations of algae is bloom, then crash and die in reply to change ecological situations. This situation cause to decrease dissolved oxygen levels. High levels of nutrients are pollution indicators from anthropogenic sources. Thus, measuring of chlorophyll can be evaluated as an indicator of levels of nutrients [1].

Using of remote sensing techniques in the estimation and creation of map of chlorophyll-a level evaluated an significant tool Materials and Methods monitoring water quality and assessment in marine and fresh waters as it is both time and economically efficient $[2,3]$.

Remote sensing technology is monitoring the water behaviour through satellites. Depending on the satellite various creates images involve of several band. Chl-a estimation is one of the best scientific applications of remote sensing $[3,4]$. Several algorithms were developed and applied to chla map in marine areas, estuaries and fresh water mass [5-8]. In the study, the show of usually used algorithms for chla prediction based on Sentinel 2A satellite images. These bands were considered through analysis of values of water surface reflectance [9]. The images results were provided spatio-temporal distribution of chla estimation in the Marmaris Bay, to better know the marine's ecosystem health and status of water quality.

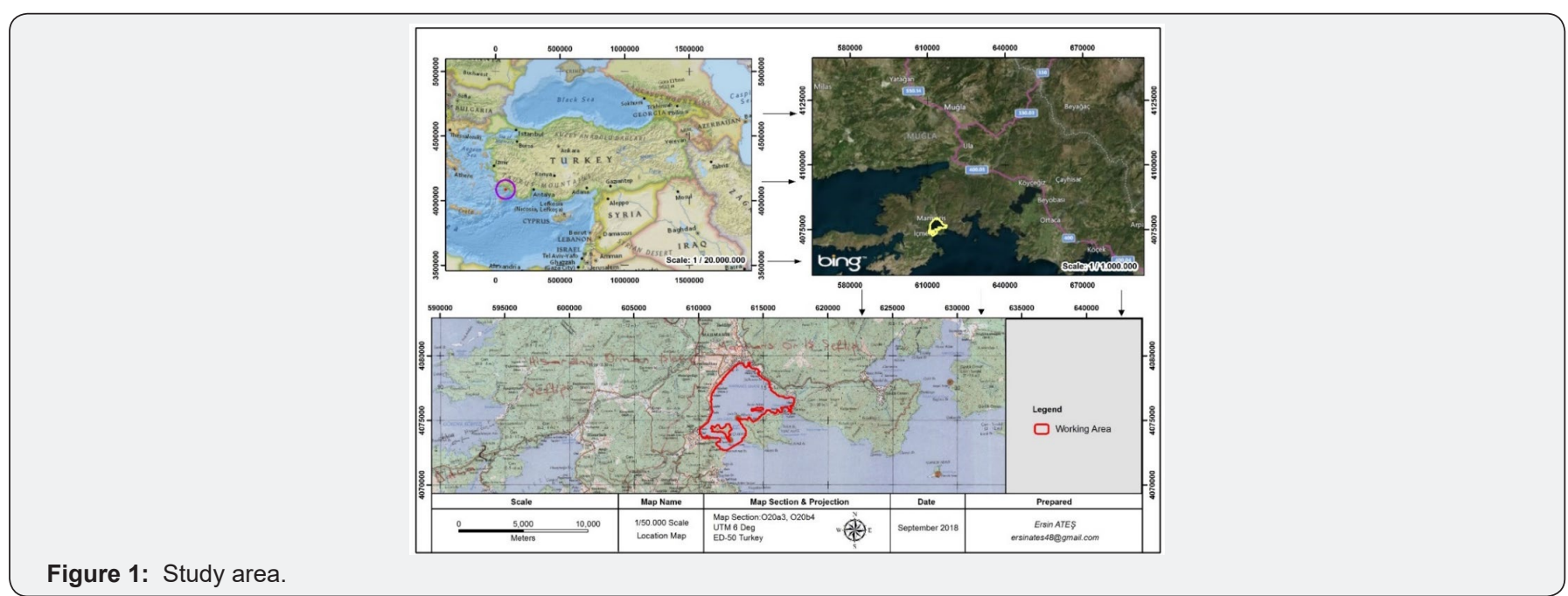


Marmaris Bay is selected as study area (Figure 1). Marmaris is a coastal city located in the district of Mugla (Southern-West of Turkey).

In this study Sentinel 2A satellite data are used, two satellite images (May 2016 and May 2018) were taken from the Marmaris Bay. Sentinel 2A images are used as a representation of the distribution of chlorophyll-a.

The processing of Sentinel 2A imagery are done using ArcGIS 10.5 software for radiometric correction, calibration, cropping and implementation of algorithm. Radiometric correction is done reducing or correct errors in the Digital Numbers (DN) of images
$[6,10]$. The process of cropping is done to minimize the image of the study area. To estimating chlorophyll-a value is using algorithm (Equation 1) to convert reflectance values of images $[4,8,11,12]$.

Equation;

$$
\text { Chla }(\mu \mathrm{g} / \mathrm{L})=((\mathrm{B} 5+\mathrm{B} 6) / \mathrm{B} 4)
$$

\section{Results}

Values of chlorophyll-a concentration in the study area, according to Sentinel 2A imagery processing, that the range values of May 2017 were estimated between 0.01-5.5 $\mu \mathrm{g} / \mathrm{L}$ (Figure 2), the values of May 2018 were estimated between 0.028-8.00 $\mu \mathrm{g} / \mathrm{L}$ (Figure 3).
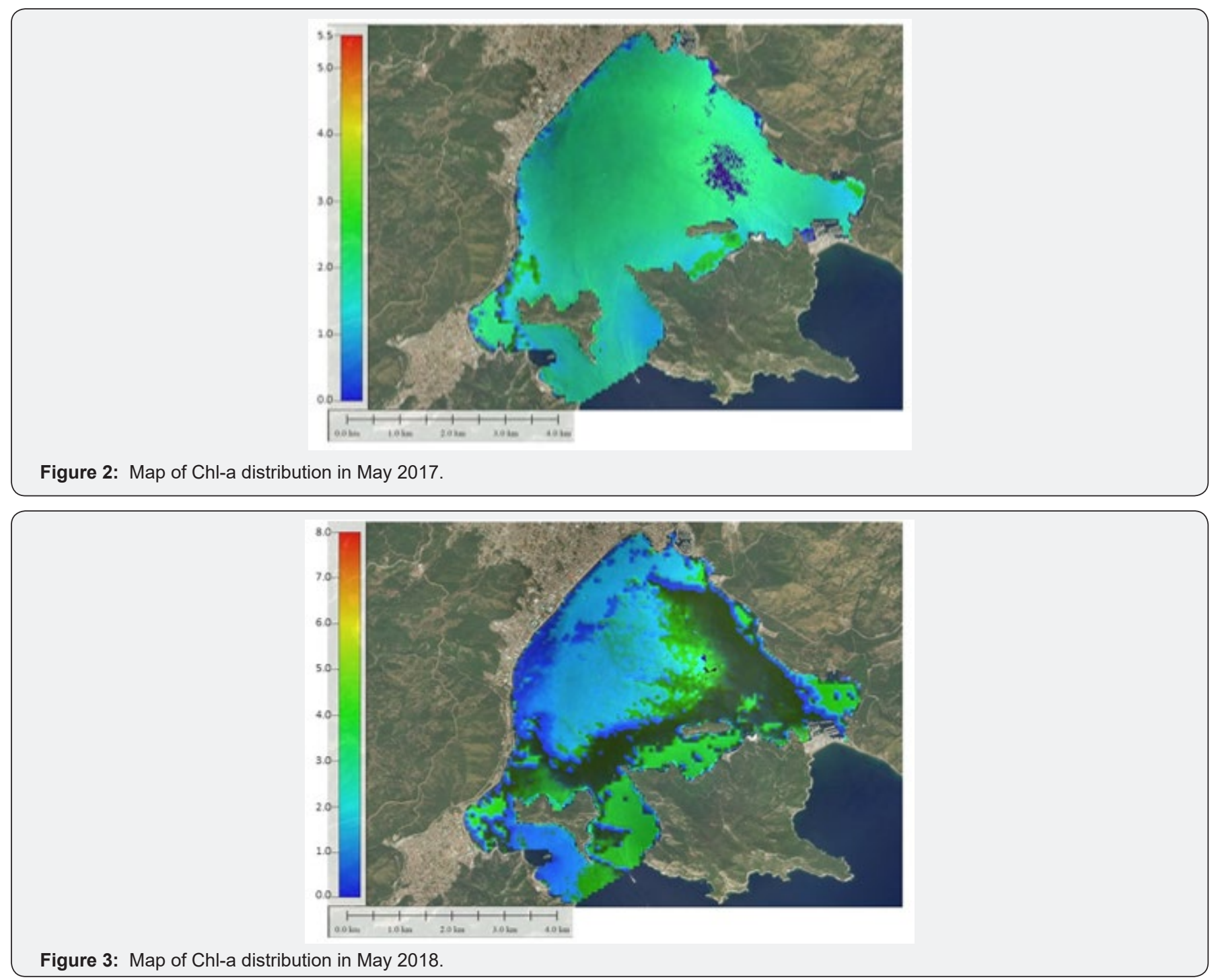

\section{Discussion}

The study discusses about the chl-a result of the applied algorithm. The chlorophyll-a values were spatially to have significant differences in the study area. In May 2018, the range of chl-a amounts were higher than May 2018. The increasing of chl-a value is evaluated an indicator of organic pollution in the marine system. Chl-a level is high in the area near with coastal zone. This reason of high production of phytoplankton might be the consequence of entry additional nutrient supply by runoff of streams flow.

\section{Conclusion}

The satellite images acquired are used in the field of studies currently. The proposed study can be applied to estimate the chl-a level in the marine areas. The algorithm which is used in the paper, was given good result in the area. The results obtained from the 
satellite images should be compared with the laboratory results and the accuracy should be confirmed.

\section{References}

1. Gitelson A (1992) The peak near $700 \mathrm{~nm}$ on radiance spectra of algae and water: Relationships of its magnitude and position with chlorophyll concentration. Int J Remote Sens 13: 3367-3373.

2. Buditama G, Damayanti A, Pin TG (2017) Identifying Distribution of Chlorophyll-a Concentration Using Landsat 8 OLI on Marine Waters Area of Cirebon, IOP Conf Ser: Earth Environ Sci 98012040.

3. Johnson RW, Harriss RC (1980) Remote Sensing for Water Quality and Biological Measurements in Coastal Waters. Photogramm Eng Remote Sens 46(1): 77-85.

4. Gholizadeh MH, Melesse AM, Reddi LA (2016) Comprehensive Review on Water Quality Parameters Estimation Using Remote Sensing Techniques. Sensors 16(8): 1298.

5. Kaymaz SM (2018) Mapping Water Quality by Using Geostatistical Method (Marmaris Bay, Mugla, Turkey). J Marin Biol Aqua Res 1(1): 103

6. Martins V, Barbosa C, Carvalho L, Jorge D, Lobo F, et al. (2017) Assessment of Atmospheric Correction Methods for Sentinel-2 MSI Images Applied to Amazon Floodplain Lakes. Remote Sens 9: 322.
7. Ritchie JC, Schiebe FR, Cooper CM, Harrington JA (1994) Chlorophyll Measurements in the Presence of Suspended Sediment Using Broad Band Spectral Sensors Aboard Satellites. J Freshw Ecol 9(3): 197-206.

8. Zhang Y, Lin H, Chen C, Chen L, Zhang B, et al. (2011) Estimation of chlorophyll-a concentration in estuarine waters: case study of the Pearl River estuary, South China Sea. Environ Res Lett 6024016.

9. Ha NTT, Thao NTP, Koike K, Nhuan MT (2017) Selecting the Best Band Ratio to Estimate Chlorophyll-a Concentration in a Tropical Freshwater Lake Using Sentinel 2A Images from a Case Study of Lake Ba Be (Northern Vietnam). ISPRS Int J Geo-Inf 6(9): 290.

10. Hanintyo R, Susilo E (2016) Comparison of Chlorophyll-a Measurement Using Multi Spatial Imagery and Numerical Model in Bali Strait Journal of Frontiers in Marine Science 4 Scopus.

11. Moses, WJ, Gitelson AA, Berdnkov S, Saprygin V, Povazhnyi V (2012) Operational MERIS based NIR-red algorithms for estimating chlorophyll-a concentrations in coastal waters - the Azov Sea case study. Remote Sens Environ 121: 118-124.

12. Supriatna L, Supriatna J, Koetsoer R (2016) Algorithm Model for The Determination of Cimandiri Estuarine Boundary Using Remote Sensing AIP Conference Proceedings.

\section{Your next submission with Juniper Publishers will reach you the below assets}

- Quality Editorial service

- Swift Peer Review

- Reprints availability

- E-prints Service

- Manuscript Podcast for convenient understanding

- Global attainment for your research

- Manuscript accessibility in different formats

( Pdf, E-pub, Full Text, Audio)

- Unceasing customer service

Track the below URL for one-step submission https://juniperpublishers.com/online-submission.php 